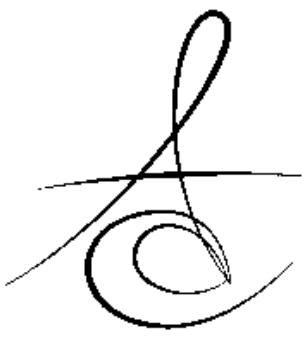

\title{
FARKLI KÖK KANAL PATLARININ SİTOTOKSİSİTE YÖNÜNDEN KARŞILAŞTIRILMASI
}

\section{COMPARISION OF CYTOTOXICITY OF DIFFERENT ROOT CANAL SEALERS}

\author{
Arş. Gör. Dt. Meşkule ŞAHİN*
}

Prof. Dr. Berna ASLAN*

Arş. Gör. Dr. Dt. Funda YILMAZ*

Makale Kodu/Article code: 3542

Makale Gönderilme tarihi: 17.01.2018

Kabul Tarihi; 29.05.2018

\section{Öz}

Amaç: Kök kanal materyalleri periapical dokular üzerinde çeşitli derecelerde sitotoksisite göstermektedir. Bu durum sonucunda sırasıyla; enflamasyon oluşumu, yara iyileşmesinin gecikmesi ve kemik rezorbsiyonu oluşmaktadır. Kök kanal dolgu materyalleri doğrudan canlı dokularla temas halinde oldukları için biyolojik olarak periapikal dokularla uyumlu olmalıdır. Çalışmamızın amacı, farklı içeriklere sahip kök kanal dolgu patlarının L-929 hücre süspansiyonudaki sitotoksik etkilerinin karşılaştırılmasıdır.

Gereç ve Yöntem: AH Plus, Tubli Seal EWT, EndoREZ, MTA Fillapex, Real Seal'in üreticilerin talimatları doğrultusunda steril şartlarda karıştırıı hazırlandı. Hazırlanan örnekler 6 kuyucuklu plağın her bir kuyucuğunda farklı kök kanal dolgu patı olacak şekilde yerleştirildi. Örnekler üzerine DMEM ilave edilerek, 24, 48 ve 72 saat bekletildi. Elde edilen ekstraksiyon sıvıları, L-929 hücre süspansiyonu içeren 96 kuyucuklu plakların her bir gözüne $100 \mu$ yerleştirildi. 48 saatlik inkübasyondan sonra plaklardan ekstraksiyon sıviları uzaklaştııılmış ve her bir göze $25 \mu \mathrm{l}$ MTT solüsyonu ilave edilerek 4 saat süre ile bekletilmiştir. Bu sürenin sonunda spektrofotometrede $570 \mathrm{~nm}$ 'de absorbanslar ölçülmüştür.

Bulgular: 24, 48 ve 72 saatlik değerlendirmede AH Plus ve kontrol grubu arasında istatistiksel olarak anlamlı bir fark gözlenmezken $(p>0,05)$, diğer kök kanal dolgu patları ve kontrol grubu arasında istatistiksel olarak anlamlı bir fark vardır $(p<0,05)$. Kontrol grubuna ait hücre canlılık oranları Tubli Seal EWT, EndoREZ, MTA Fillapex ve Real Seal kök kanal dolgu patlarının hücre canlılık oranlarından anlamlı derecede daha yüksektir.

Sonuç: AH Plus 3 zaman diliminde de sitotoksisite göstermezken, Tubli Seal EWT, EndoREZ, MTA Fillapex ve Real Seal 24. ve 48. saatlerde orta, 72 . saatte ise hafif sitotoksisite göstermişlerdir.

Anahtar Kelimeler: Kök kanal dolgu patları, MTT testi, sitotoksisitet

\section{ABSTRACT}

Aim: Root canal sealers exhibit varying degrees of cytotoxicity to periapical tissues. This in turn results in inflammation, delayed wound healing, and even bone resorption. Root canal sealers were contact with periapical tissues and must be biocompatable. The aim of this study was to compare the cytotoxic effect of different root canal sealers in different contents on L-929 cell suspension.

Materyal and Methods: AH Plus, Tubli Seal EWT, EndoREZ, MTA Fillapex and Real Seal were mixed under sterilized condition according to manufacturer's instructions. Mixed sealers were placed in six-well plate and every sealers placed at the bottom of each well to cover an area of $1 \mathrm{~cm}$ diameter. Placed DMEM on samples for 24,48 and 72 hours. $100 \mu$ of eluate was transferred to a $96-$ well plate containing L-929 cell suspension. After 48 hours incubation the extracts were removed from the wells, $25 \mu \mathrm{M}$ MTT solution was added to each well and waited for 4 hours. Subsequently, the spectrophotometric absorbance was measured at $570 \mathrm{~nm}$ using a spectrophotometer.

Results: According to the MTT assay, in the rates of cell viability there was no statistically significant difference between AH Plus and control group at 24, 48 and 72-hour evaluation $(p>0.05)$, but there was statistically significant difference between the other sealers and control group $(p<0.05)$. The control group had significantly high rates of cell viability than Tubli Seal EWT, EndoREZ, MTA Fillapex and Real Seal.

Conclusion: For each 24, 48 and 72 hours AH Plus was non-cytotoxic, Tubli Seal EWT, EndoREZ, MTA Fillapex and Real Seal had moderate cytotoxicity at 24 and 48 hour evaluation and slightly cytotoxicity at 72 hour evaluation.

Key Words: Cytotoxicity, MTT assay, root canal sealers

* Ankara Üniversitesi Diş Hekimliği Fakültesi, Endodonti AD, Ankara 


\section{GİRİŞ}

Kök kanal patları kimyasal içeriklerine göre; çinko oksit-öjenol, kalsiyum hidroksit, cam iyonomer, silikon, rezin ve mineral trioksit aggregate esaslı olmak üzere sınıflandırılabilmektedir. Birçok çalışmada kök kanal dolgu patlarının fiziksel ve biyolojik özellikleri değerlendirilmiş ve ideal bir kök kanal patında bulunması gereken özellikler tarif edilmiştir. ${ }^{1-6} \mathrm{Bu}$ materyallerin kök kanalından apikal foramen veya yan kanallar vasıtasıyla doğrudan canlı dokularla teması söz konusudur. Bu nedenle temel özellikler değerlendirildiğinde biyouyumluluk bu materyaller için en temel özellik niteliğindedir.

Biyouyumluluğun belirlenmesinde materyallarin canlı hücreler üzerine etkisi sitotoksik olarak incelenerek tespit edilebilmektedir. ${ }^{3-8}$ Kullanılan bu materyaller doğrudan canlı dokularla temas halinde olabilirler veya çözündüklerinde içerdikleri bazı maddelerin salınımı dokuları etkileyebilir. Sitotoksik etki sonucu oluşan inflamatuar cevap; periapkal dokularda yıkıma, alveolar kemik rezorbsiyonuna ve sonuç olarak dişin kaybına neden olabilir. Bu maddelere karşı oluşan doku yanıtı, oldukça önemlidir. Bu nedenle bu materyaller biyolojik olarak uyumlu olmalı ve periapikal dokular tarafından tolere edilebilmelidir., ${ }^{9,10}$

Rezin içerikli kök kanal patları çeşitli derecelerde biyouyumluluk göstermektedir. ${ }^{2,3,8,10}$ EndoRez (Ultradent, South Jordan, UT, ABD) ve Real Seal (Sybron Endo, California, ABD) metakrilat rezin esaslı kök kanal patlarıdır. Endo Rez Üretan dimetakrilat matriksi (UDMA) içinde çinko oksit, baryum sülfat ve pigmentlerin bulunduğu bir reçinedir. UDMA kompozit reçinelerin organik matriksini de oluşturan bir monomerdir. Hafif derecede toksik olduğunu belirten çalışmalar vardır. Real Seal, dual sertleşen rezin esaslı kompozit bir pattır ve asidik ortamda uygun otopolimerizasyon imkanı tanıyan bir redoks katalizörü içerir. Rezin matriks, bisfenol-A glisidil metakrilat (Bis GMA), etoksillenmiş Bis GMA, üretan dimetakrilat ve hidrofilik difonksiyonel metakrilatların karışımıdır. ${ }^{2,8}$ AH Plus (Dentsply De Trey GmbH, Konstanz, Almanya) ise epoksi rezin esaslı bir kök kanal patıdır. ${ }^{2,5}$ Tubli Seal EWT (Kerr, Romulus, MI, ABD) çinko oksit öjenol içerikli kök kanal patıdır. Çinko oksit öjenol, çinko oksit öjenolat kristalleri matriksi arasına gömülmüş ve sertleşmiş çinko oksit kristalleri oluşturarak donan bir bileşiktir. En önemli dezavantajı ise, sürekli öjenol salınımı ile birlikte suyla temas ettiğinde dekompoze olmasıdır.,11 MTA-Fillapex (Angelus, Londrina, Brazilya) içeriğinde mineral trioksit aggregate (MTA) ve silica nanopartikülleri içeren silikat rezin bir kök kanal patıdır.6,11,12

Hücre kültürü kök kanal patlarının sitotoksisitesini belirlemekte seçilebilecek yöntemlerden biridir. Metil tiyazol tetrazolyum (MTT) 3- (4,5-dimetiltiyazol-2-il) -2,5-difeniltetrazolyum bromür hücre kültürü testi sitotoksisite ve hücre canlılığının belirlenmesinde yaygın olarak kullanılmaktadır. Bu test MTT'yi mavi, çözünmeyen formazan bileşiğine dönüştürebilen mitokondriyal dehidrogenaz enzim aktivitesini ölçmektedir. Hücrelerde uygulanan maddenin sitotoksik etkisi nedeniyle dehidrogenaz aktivitesinin etkilendiği koşullarda mavi renkli formazan oluşmamaktadır. ${ }^{18,19}$ Çalışmamızda kullanılan kök kanal patları sitotoksisite yönünden L 929 hücre süspansiyonunda in vitro olarak karşılaştırılmıştır.

Çalışmamızın amacı, klinikte kullanılmakta olan farklı içeriklere sahip kök kanal dolgu patlarından AH Plus, Tubli Seal EWT, EndoREZ, MTA Fillapex ve Real Seal'ın L-929 hücre süspansiyonudaki sitotoksik etkilerinin karşılaştırılması ve biyolojik uyumluluklarının değerlendirilmesidir.

\section{GEREÇ VE YÖNTEM}

$\mathrm{Bu}$ in vitro çalışma için 5 farklı kök kanal dolgu patı seçilmiştir: AH Plus (Dentsply DeTrey, Konstanz, Almanya), Tubli Seal EWT (Kerr, Michagen, $A B D$ ) EndoREZ (Ultradent Corp, Utah, ABD) MTA Fillapex (Angelus, Londrina, Brezilya) ve Real Seal (Sybron Endo, California, ABD). Çalışmamızın sitotoksisite değerlendirmeleri, Ankara Üniversitesi Biyoteknoloji Enstitüsü Merkez Laboratuarları'nda yürütülmüştür. Çalışmada kök kanal dolgu patlarının sitotoksik etkilerinin araştırılması amacıyla hücre kültürü deneyleri yapılmış ve beş farklı kök kanal patının etkileri araştırımıştır.

\section{Örneklerin Hazırlanması}

Deneyde kullanılacak kök kanal dolgu patları üretici firmanın talimatları doğrultusunda steril kabin (Class II Holten LominerHow, Danimarka) içerisinde aseptik şartlarda hazırlanmıştır. 6 kuyucuklu plağın her bir kuyucuğuna her kuyucuğa farklı kök kanal

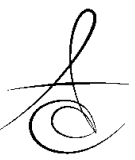


dolgu patı $1 \mathrm{~cm}$ çapında alanı kaplayacak şekilde yerleştirilmiştir.

\section{Ekstraksiyon SIvısı Elde Edilmesi}

Kök kanal patları 6 kuyucuklu plaklara yerleştirildikten sonra bakteriyel kontaminasyonu önlemek amacı ile materyaller 24 saat süreyle ultraviyole ışığında bekletilmiş daha sonra $6 \mathrm{ml}$ kültür ortamı Dulbecco's Modified Eagle Medium (DMEM/F12) (Biochrom Ag, Berlin, Almanya) ilave edilerek, $37^{\circ} \mathrm{C}$, $\% 100$ nemli ortamda, $\% 5 \mathrm{CO} 2$ içeren atmosfere sahip inkübatörde (Heracell, Hessen, Almanya) 48 saat süreyle bekletilmiştir. 48 saat sonra aspire edilen kültür ortamı steril santrifüj tüplerine aktarılmış ve deney materyali olarak kullanılmıştır. Elde edilen ekstraksiyon sıvıları hücre canlılık testinde kullanilıncaya kadar $-20^{\circ} \mathrm{C}$ 'de saklanmıştır.

\section{Hücre Kültürü Hazırlanması}

Deneylerde L-929 fare derisi fibroblastları (L-929 HÜKÜK 95030802, Şap Enstitüsü, Ankara, Türkiye), kültür ortamı olarak ise antibiyotik içermeyen, \%10 fetal sığır serumu (Biochrom Ag, Berlin, Almanya) ile desteklenmiş DMEM kullanılmıştır. Ankara Şap Enstitüsü hücre kültürü koleksiyonundan (HÜKÜK) temin edilen, dondurulmuş haldeki L-929 fare fibroblast hücreleri ampül içinde $37^{\circ} \mathrm{C}$ su banyosunda 1-2 dakika bekletildikten sonra bir pipet ile hemen önceden $37^{\circ} \mathrm{C}$ 'ye ısıtılmış besiyeri içeren steril santrifüj tüpüne aktarılmıştır. Hücrelerin yapıştığı gözlendikten sonra besiyeri vakumla çekilmiş, 1-2 ml PBS (Dulbecco's phosphate buffered saline, Stem Cell Technologies, Vancouver, Kanada) ile bir kez yıkandıktan sonra \%0,05 / \%0,02 TripsinEDTA (PAA, Pasching, Avusturya) solüsyonu ilave edilerek yaklaşık 1 dakika \%5 $\mathrm{CO} 2$ içeren inkübatörde bekletilmiştir. Hücrelerin yüzeyden kalktığı ters mikroskopta gözlendikten sonra vakit kaybetmeden yeterli miktarda besiyeri içerisine alınarak 900 RCF 4 dakika santrifüj edilmiş, üst faz vakumla çekildikten sonra altta kalan hücreler besiyerinde homojenize edilerek 3 ayrı T-25 hücre kültürü kabına (Orange Scientific, Braine-l'Alleud, Belçika) alınarak \%5 CO2 içeren atmosferde $37^{\circ} \mathrm{C}^{\prime}$ de kültüre edilmiştir. Bu işlemler hücrelerin büyüme-yapışma durumları kontrol edilerek ve uygun zamanda pasajlanarak hücreler 2. pasajda elde edilmiştir.

\section{MTT (Mitokondrial Dehidrogenaz Aktivitesi) Yöntemi ile Hücre Canlıık Tayini}

MTT stok solüsyon: MTT $5 \mathrm{mg} / \mathrm{ml}$ olacak şekilde PBS içerisinde çözülmüş ve $0,2 \mathrm{~mm}$ filtreden geçirilmiştir. MTT çalışma solüsyonu: MTT stok solüsyonunun DMEM ile 1:10 dilüsyonu hazırlanmıştır. Kök kanal patlarına DMEM ilave edildiği esnada eş zamanlı olarak L-929 hücre süspansiyonu $3.10^{4}$ hücre/ ml olacak şekilde hazırlanmış ve 96 kuyucuklu hücre kültürü plaklarına her bir kuyucuğa $100 \mu$ olacak şekilde eklenerek hücre çoğalması için \%5 CO2 içeren $37^{\circ} \mathrm{C}$ 'lik inkübatörde 48 saat bekletilmiştir. Tüm deney işlemleri 4 kez tekrarlanmıştır. 48 saat sonunda kuyucuklardaki deney ortamı uzaklaştırılarak yerine her bir kuyucuğa $100 \mu$ l olacak şekilde deney materyali eklenmiştir. Kontrol grubuna ise $100 \mu \mathrm{l}$ DMEM/F12 ilave edilmiştir. Farklı saatlerdeki sitotoksisiteyi ölçebilmek amacı ile 3 adet 96 kuyucuklu plak (24, 48 ve 72. saatler için) ayrı ayrı hazırlanmıştır. 24 saat sonunda 24. saat olarak etiketlenen 96 kuyucuklu plak inkübatörden çıkarılarak besiyeri ortamdan uzaklaştırımış, önceden su banyosunda $37^{\circ} \mathrm{C}$ ye ısıtılmış PBS ile yıkandıktan sonra her bir kuyucuğa $100 \mu$ l DMEM ve 25 $\mathrm{ll}$ MTT çalışma solüsyonu (3-[4,5-dimethylthiazol-2yl]-2,5-diphenyltetrazolium bromide) ilave edilerek karanlık ortamda $37^{\circ} \mathrm{C}$ de 4 saat süre ile bekletilmiş süre bitiminde hücre kültürü plaklarındaki tüm sıvılar aspire edilmiş ve her bir göze $100 \mu$ DMSO (dimetil sülfoksit, Riedel de Haën, Almanya) ve $12,5 \mu \mathrm{l}$ glisin tamponu (0,1 M Glisin, 0,1 M NaCl, pH: 10.5) eklenmiştir. Hemen ardından spektrofotometrede (Spectramax M2, Molecular Devices, California, ABD) 570 nanometrede absorbansları ölçülmüştür. Bu işlemler 48. ve 72. saatler için de aynı şekilde uygulanmıştır. Tüm deney işlemleri ve MTT testi dört kez tekrarlanmıştır.

\section{İstatistiksel Analiz}

Deney sonucunda elde edilen verilerin analizinde IBM SPSS Statistics 19 paket programı (IBM, New York, ABD) kullanılmıştır. Farklı zamanlar için patlar arasında farklılık olup olmadığını test etmek amacıyla parametrik olmayan Kruskal-Wallis Testi kullanılmış, analiz sonucunda fark çıkan gruplarda farkın kaynağını bulmak için LSD (Least Significant Difference) testi uygulanmıştır. Ayrıca farklı zamanlar için her bir pat ile kontrol grubu arasında farklılık olup olmadığını test etmek amacıyla Mann-

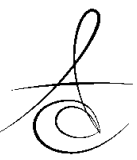


Whitney U Testi kullanılmıştır. Farklı patların zamana göre değişiminin anlamlı olup olmadığını test etmek amacıyla ise parametrik olmayan Friedman Testi kullanılmış, analiz sonucunda fark çıkan gruplarda farkın kaynağını bulmak için LSD testi uygulanmıştır

\section{BULGULAR}

Kök kanal dolgu patlarının sitotoksik etkilerinin 24., 48. ve 72. saatlerdeki incelenmesi sonucunda elde edilen hücre canlılık oranları, kök kanal dolgu patlarına ait ekstraksiyon sıvılarının hücre kültürleri üzerine uygulanmasından sonra MTT testi ile elde edilen optik densitometre değerlerinin, kontrol grubu optik densitometre değerlerine oranı (\%) hücre canlılığı olarak ifade edilmiş ve her grubun kendi kontrol grubunun hücre canlılık oranlarının \%100 olduğu kabul edilerek hesaplamalar yapılmıştır. Çalışmamızdaki gruplara ait 24., 48. ve 72. saatteki hücre canlılık oranlarının ortalama değerleri Tablo 1'de gösterilmiştir.

Mosmann (1983) deney materyali uygulandıktan sonraki hücre canlılığı oranına göre sitotoksik etkiyi aşağıdaki skala ile derecelendirmiştir: ${ }^{13}$
- \%60-90 arası hücre canlılığı varlığı - hafif derecede sitotoksik

- %30-59 arası hücre canlılığı varlığı - orta derecede sitotoksik

- \%30 ve altı hücre canlılığı varlığı - şiddetli derecede sitotoksik

Çalışmamızda bu sınıflama esas alınarak elde edilen hücre canlılık oranlarına göre kök kanal dolgu patlarının sitotoksisite dereceleri Tablo 2'de gösterilmiştir.

Mann-Withney U testi sonucunda 24, 48 ve 72 saatlik değerlendirme periyodunda kontrol grubu ile AH Plus grubu arasında anlamlı bir farklılık bulunmamıştır $(p>0,05)$. Ancak kontrol grubu ile Tubli Seal EWT, EndoREZ, MTA Fillapex ve Real Seal grupları arasında anlamlı bir farklılık olduğu tespit edilmiştir $(p<0,05)$. Ayrıca ilk 24 saatlik değerlendirmede çalışma grupları arasında canlı hücre oranları bakımından anlamlı bir farklılık bulunmuştur $(p<0,05)$. Buna göre; AH Plus grubundaki canlı hücre oranı diğer gruplarından anlamlı derecede daha yüksek bulunmuştur.

Tablo 1. AH Plus, Tubli Seal EWT, EndoREZ, MTA Fillapex, Real Seal kök kanal dolgu patlarının 24., 48. ve 72 . saatteki hücre canlılık oranlarının (\%) ortalama değerleri (minimum- maksimum).

\begin{tabular}{|l|c|c|l|}
\hline Gruplar & 24. Saat & 48. Saat & 72. Saat \\
\hline AH Plus & $91,93(81,86-100,08) \mathrm{a} *$ & $99,22(93,66-103,94) \mathrm{a}$ & $100,63(94,12-109,58) \mathrm{a}$ \\
\hline Tubli Seal EWT & $55,28(51,46-58,16) \mathrm{b}$ & $53(37,85-62,91) \mathrm{b}$ & $70,39(66,74-72,98) \mathrm{b}$ \\
\hline EndoREZ & $53,83(51,45-57,07) \mathrm{b}$ & $55,82(51,58-63,1) \mathrm{b}$ & $66,62(62,79-71,93) \mathrm{b}$ \\
\hline MTA Fillapex & $55,9(54,42-56,92) \mathrm{b}$ & $46,77(38,53-57,49) \mathrm{b}$ & $66,98(59,62-78,44) \mathrm{b}$ \\
\hline Real Seal & $52,12(46,7-57,16) \mathrm{b}$ & $43,63(35,45-53,72) \mathrm{b}$ & $60,92(56,35-65,11) \mathrm{b}$ \\
\hline Kontrol & $100(98,18-101,94) \mathrm{a}$ & $100(93,95-104,75) \mathrm{a}$ & $100(88,3-105,95) \mathrm{a}$ \\
\hline
\end{tabular}

* Dikey sütunda farklı harfler taşıyan değerler arasındaki farklılıklar istatistiksel olarak anlamlıdır $(p<0,05)$

Tablo 2. Mosmann (1983)'ın skalasına göre AH Plus, Tubli Seal EWT, EndoREZ, MTA Fillapex, Real Seal kök kanal dolgu patlarının sitotoksisitedeğerleri.

\begin{tabular}{|c|c|c|c|}
\hline & 24. Saat & 48. Saat & 72. Saat \\
\hline AH Plus & Sitotoksik Değil & Sitotoksik Değil & Hafif \\
\hline Tubli Seal EWT & Orta & Orta & Hafif \\
\hline EndoREZ & Orta & Orta & Hafif \\
\hline MTA Fillapex & Orta & Orta & Hafif \\
\hline Real Seal & Orta & Orta & \\
\hline
\end{tabular}


teki canlı hücre oranlarının 24 ve 48 . saate göre anlamlı derecede daha yüksek olduğu tespit edilmiştir $(p<0,05)$. RealSeal grubunda ise en fazla hücre canlıık oranının 72. Saatte olduğu en az oranın ise 48. Saat sonunda ve gruplar arası faklılığın anlamlı olduğu tespit edilmiştir.

\section{TARTIŞMA}

Endodontik dolgu materyalleri canlı dokular ile doğrudan ilişkide olduğundan, bu materyallere karşı oluşabilecek doku cevabı önemlidir. Ayrıca bazı mikroorganizmalar dentin tübüllerinde ilerleyip canlııklarını koruyarak patojenitelerini devam ettirebilmektedirler. ${ }^{14-16}$ Bu nedenle, kök kanal tedavisinde kullanılan kök kanal dolgu maddelerinin antibakte riyel etkiye sahip olmaları istenmektedir. Ancak kök kanal dolgu patları canlı periapikal dokular ile temasta olacağı için bu materyallerin antibakteriyal etkinliğnin yanında dokulara biyouyumlu olması da gerekmektedir. Aksi halde periapikal bölgelerdeki hücreler üzerinde stres oluşturarak, hücrelerin yapısında, proliferasyonunda, adezyonunda ve enzim sistemlerinde dejenerasyonlara neden olabilmektedir. ${ }^{17}$

Hücre kültürü çalışmaları, endodontik tedavilerde kullanılan materyallerin hücresel yanıtlarını belirleyebilmek ve biyouyumluluklarını değerlendirebilmek amacıyla kullanılan in vitro test yöntemleridir. ${ }^{18-24}$ Cartwright ve Shah, hücre kültürü çalışmalarında sitotoksik ve genotoksik etkilerin, pek çok fiziko-kimyasal ve fizyolojik değişkenlerden uzak olarak incelenebildiğini bildirmişlerdir. Bu testler sırasında, ISI, pH, osmotik basınç, oksijen ve karbondioksit tansiyonu gibi çevre şartları da kontrol altındadır. ${ }^{18}$ Bu nedenlerle bizim çalışmamızda da sitotoksik etkinin değerlendirilmesinde hücre kültürü yöntemi tercih edilmiştir. Hücre kültürü çalışmasında kullanılmak üzere seçilen hücre tipi, toksisitesinin belirlenmesi amaçlanan materyalin kullanım sahası ile ilişkili olarak seçilmelidir. ${ }^{18}$ Bizim çalışmamızda L- 929 hücre kültürü kullanıııştır. Taira ve ark.'da dental materyallerin sitotoksisitelerinin belirlenmesinde hücre tipleri içerisinde en duyarlı ve güvenilir şekilde kullanılabilecek hücre kültürü ortamını L- 929 fare fibroblastları olduğunu belirtmişlerdir. ${ }^{26}$ Ayrıca ISO 10993-5 (1999) sitotoksisite testleri, in vitro yöntemler standartlarına göre; dental materyallerin sitotoksik etkilerinin araştırımasında standart olarak L-929 ya da Balb/ 3T3, WI38 gibi hücre tipi kültürlerinin kullanılmasını önermektedir. ${ }^{12,20,21}$

Çalışmamızda AH Plus, Tubli Seal EWT, EndoREZ, MTA Fillapex, Real Seal kök kanal dolgu patlarının L- 929 hücre kültüründe sitotoksisitelerinin değerlendirilmesinde materyallerin 24,48 ve 72 saatlik ekstraksiyon sıvıları incelendiğinde, Mosmann'ın sınıflamasına gore, tüm zaman dilimlerinde AH Plus kök kanal dolgu patının sitotoksik etki göstermediği, diğer kök kanal dolgu patları ise 24 ve 48 saatlik zaman dilimlerinde orta derecede sitotoksisite, 72 saatlik zaman diliminde ise sitotoksik etkileri önemli ölçüde azalma gösterdiği, Real Seal'in ise 48. saatte en yüksek sitotoksik etkiye sahip olduğu istatistiksel olarak belirlenmiştir. Ayrıca MTT testi sonuçları istatistiksel olarak değerlendirildiğinde; 24,48 ve 72 saatlik sürelerde hücre canlılık oranları açısından Tubli Seal EWT, EndoREZ, MTA Fillapex, Real Seal arasında sitotoksisite açısından anlamlı bir fark gözlenmezken epoksi rezin içerikli AH Plus'ın diğer deney gruplarından daha iyi sonuç verdiği tespit edilmiştir. $\mathrm{Bu}$ sonuç daha once yapılan bazı çalışmalarla benzerlik göstermektedir. ${ }^{26-28}$ Azar ve ark.'ları yaptıkları çalışmada AH Plus'ın karıştıııııktan 4 saat sonra sitotoksisite göstermediğini tespit etmişlerdir. ${ }^{26}$ Çalışmamız sonucunda gözlenen Tubli Seal EWT'nin sitotoksisitesi ise; kök kanal dolgu patının içeriğinde bulunan öjenolden kaynaklanmış olabilir. Çinko oksit ve öjenol karıştıııldığında şelasyon reaksiyonu meydana gelmekte ve sonuçta içerisinde çinko oksit kristalleri bulunan, çinko öjenolat matriksi oluşmaktadır. Yapılan hücre kültürü ve doku implant çalışmalarında, bu matriks içinde reaksiyona girmemiş veya hidroliz ile sertleşebilen öjenolün toksik etkilere yol açabileceği bildirilmiştir. Ayrıca metil salisilik asit, benzyl alkol, çinko iyonları ve reçine salınımı çinko oksit ojenol içerikli kök kanal patlarının sitotoksik yapısına katkıda bulunmuş olabilir. ${ }^{20,21,27}$

EndoREZ'In yapısında bulunan üretan dimetakrilat (UDMA), bu patın sitotoksik etkisinden sorumlu tutulabilir. UDMA'nın toksik bir ajan olduğu daha önceki çalışmalarda da öne sürülmüştür. UDMA'nın düşük konsantrasyonda ve çok kısa zaman periyotlarında bile sitotoksik tahribatların başlamasından önce görülen bir reaksiyon olan 
intraselüler glutatyon seviyesinde azalmaya neden olarak hücrede hasara yol açabilmektedir. ${ }^{2,8,25}$ Real Seal da yapısında UDMA, PEGDMA, Bis-GMA ve benzeri rezin içermektedir. Real Seal'ın \%60'ı rezin kompanentlerden oluşmaktadır. Sitotoksisitesi yüksek rezin içeriğine ve patın tamamen polimerize olmamasına bağlanabilir. Real Seal genellikle anaerobik ortamda 30 dakikada sertleşirken, ortamda hava varlığında kök kanal dolgu patının yüzeyi bir hafta sonra sertleşmektedir. Çünkü oksijen rezinlerin polimerizasyonunu inhibe etmektedir. ${ }^{2,3,8,25}$ Bizim çalışmamızda, kök kanal patı işlem görmeden önce 24 saat $37^{\circ} \mathrm{C}$ de saklanmış fakat hava ile tamamen teması kesilmemiştir. Bu yüzden kök kanal dolgu patının yüzeyi tamamen sertleşmeyip, polimerize olmamış toksisiteye neden olabilecek asidik monomerler açığa çıkmış olabilir.

MTA Fillapex'in başııca bileşeni salisilat rezin olup daha az miktarda MTA içermektedir. MTA Fillapex kalsiyum silikat simanlara gore daha az su çeker böylece daha az $\mathrm{Ca}^{2+}$ salınımı, alkalize aktivite ve apatit birikimi gösterir. Bu durum, salisilat rezin matrisinin MTA'yı daha inert hale getirdiği varsayımıyla ilişkilendirilebilir. Ayrıca salisilat rezinler, biyoaktif bileşenlerle dolgu maddelerinin fizikokimyasal özelliklerini ve uygulama özelliklerinin iyileştirilmesine katkı sağlamaktadır. MTA-Fillapex'in içeriğindeki rezin ve MTA arasındaki dengesiz oran nedeniyle oldukça yüksek akışkanlık ve uzun sertleşme süresi göstermektedir. Bu durum, toksik bileşiklerin uzun süreli çözünmesine ve sitotoksisitenin artmasına sebep olmaktadır.,11,28 Bizim yaptığımız çalışmada MTA Fillapex ortadan hafife doğru değişen derecelerde sitotoksik bulunmuştur. Bu sitotoksik etkinin sebebinin içeriğinde bulunan rezin komponentlerden kaynaklandığını düşünmekteyiz.

Polimerizasyon reaksiyonu sonucu sertleşen kök kanal dolgu patları, kök kanalı içine taze karıştırılmış olarak yerleştirilmektedir ve bu patların birçoğu doku hasarına neden olmaktadır. Polimerizasyon işlemi ilerledikçe, toksik serbest radikaller, reaksiyona uğramamış metakrilatlar ve askıda kalan metakrilatlar azalmaktadır. Bu durum materyallerin sitotoksik etkisinin zamanla azalmasının sebebi olabilir. Çalışmamızda kullandığımız kök kanal dolgu patlarının 72 . saatte sitotoksik etkilerinin azalmış olması da bu duruma bağlanabilir. ${ }^{29}$
Yapılan bir çalışmada AH Plus, RoekoSeal, EndoREZ, Epiphany ve Activ GP kök kanal dolgu patlarının sitotoksisitesi, 24 ve 72 saatlik dilimde değerlendirilmiştir. ${ }^{30} \mathrm{AH}$ Plus'ın sitotoksik bulunmaması yönüyle bizim çalışmamızı desteklemektedir. Ancak EndoREZ kök kanal dolgu patı ise bizim çalışmamızdan farklı olarak sitotoksik etki göstermemiştir. Bu farklılığın nedeni deney koşulları, materyallerin hücrelerle temas şekli, ekstraksiyon sıvılarının elde ediliş yönteminin farklıı̆ı olabilir. Ayrıca Real Seal ile aynı içeriğe sahip Epiphany sitotoksik bulunması yönüyle bizim çalışmamızla benzerlik göstermektedir.

AH Plus kök kanal dolgu patının sitotoksik ve genotoksik etkilerini iki farklı hücre dizini ve dört farklı yöntemle değerlendirildiği diğer bir çalışmada AH Plus'ın genotoksik ve sitotoksik etkisi olmadığı sonucuna varılmıştır. ${ }^{31}$ Çalışmada Kullanılan hücre tipi ve analiz yöntemi bizim çalışmamızdan farklı olmasına rağmen sonuçlar çalışmamızla paralellik göstermektedir. AH Plus' in sitotoksik etkiye sahip olmaması yapısında bulunan ve sıvılarda çözünebilen sitotoksik kompanentlerinin az miktarda salınmasına bağlanmıştır. Bizim çalışmamızda da patların ekstraksiyon sıvılarının kullanılmış ve $A H$ Plus'ın sitotoksik etki göstermemesi benzer nedenlerle açıklanabilir. Ayrıca AH Plus'ın sitotoksik etkisinin olmadığını gösteren birçok çalışma ile sonuçlarımız benzerlik göstermektedir. ${ }^{26-28}$

İnsan gingival fibroblastları ve L-929 fare fibroblast hücrelerini kullanıldığı başka bir çalışmada farklı kök kanal patlarının sitotoksik etkileri değerlendirilmiş ve çalışmanın sonucunda rezin-bazlı (Epiphany, EndoREZ) kök kanal dolgu patları ve kalsiyum hidroksit-bazlı (Apexit, Acroseal) kök kanal dolgu patları diğer patlardan anlamlı olarak daha sitotoksik bulunmuştur. ${ }^{32}$ Bu çalışma Real Seal kök kanal dolgu patı ile aynı içeriğe sahip Epiphany ve bir diğer rezin içerikli kök kanal dolgu patı olan EndoREZ' in $\mathrm{AH}$ Plus kök kanal dolgu patından daha fazla sitotoksik etki göstermesi yönüyle bizim çalışmamızla paralellik göstermektedir.

Keleş ve ark. ${ }^{33}$ yaptıkları bir çalışmada ise $\mathrm{AH}$ Plus, AH 26, Endomethasone N , RoekoSeal ve Sealapex kök kanal patlarının 3T3 fare fibroblastları üzerinde oluşturdukları sitotoksisiteyi 1,4 ve 7 günlük ekstraksiyon periyotlarında incelemişler ve kanal patlarını, sitotoksisite derecelerine göre , Sealapex > 
AH $26>$ Endomethasone $\mathrm{N}>$ AH Plus > RoekoSeal olarak sıralamışlardır. Elde ettikleri sonuçlara göre $A H$ Plus'ın hafif sitotoksik etki gösterdiğini bulmuşlardır. Bunun nedenini içeriğindeki epoksi rezin içeriğine bağlamışlardır.

Sealapex, Root Canal Sealer EWT, Real Seal ve MTA Fillapex kök kanal dolgu patlarının sitotoksik etkilerini insan osteoblastları üzerindeki sitotoksik etkisinin XTT analizi, nötral kırmızı ve kristal viyole boya testleri kullanarak değerlendirildiği diğer bir çalışmada, 24 saat sonunda bütün patların şiddetli sitotoksik etkileri olduğu belirtilmiştir. ${ }^{34}$ Bizim çalışmamızda ise 24 saat sonunda Real Seal ve MTA Fillapex kök kanal dolgu patları orta derecede sitotoksik etki göstermiştir. Bu farklılı̆a sitotoksisiteyi değerlendirme yöntemi ve kullanılan hücre tipinin farklılığı sebep olmuş olabilir.

Sonuç olarak, yaptığımız bu çalışmada, sitotoksik etkilerini incelediğimiz 5 farklı kök kanal dolgu patından AH Plus sitotoksik etki göstermediği gözlenmiştir. Tubli Seal EWT, EndoREZ ve MTA Fillapex kök kanal dolgu patlar ortadan hafife değişen oranlarda sitotoksik etki göstermektedir. Real Seal'in ise 48. saatte en yüksek sitotoksik etkiye sahip olduğu istatistiksel olarak belirlenmiştir. Hücre canlılık oranları açısından 24, 48 ve 72 saatlik sürelerde Tubli Seal EWT, EndoREZ, MTA Fillapex, Real Seal grupları arasında anlamlı bir fark gözlenmezken AH Plus grubunun diğer deney gruplarından daha iyi sonuç verdiği tespit edilmiştir. Böylece çalışmamızın sonuçları doğrultusunda $\mathrm{AH}$ Plus'ın biyolojik olarak en uyumlu kök kanal dolgu patı olduğu bulunmuştur.

Meşkule Şahin: ORCID ID: 0000-0002-8770-8815 Berna Aslan: ORCID ID: 0000-0002-4673-7791 Funda Yilmaz: ORCID ID: 0000-0003-0815-5907

\section{KAYNAKLAR}

1. Himel VT, Mcspadden JT, Goodis HE. Instruments, materials, and devices. In: Pathways of the Pulp. "9nd Ed." Cohen, S., Hargreaves, K.M., St. Louis: Mosby 2006: p.233290.

2. Schmalz G, Arenholt-Bindslev D. Root canal filling materials. In: Textbook of Endodontology "2th ed." Ed. Bergenholtz, G., Hørsted-Bindslev, P., Reit, C., West Sussex. John Wiley \& Sons. 2010: p.193-218.
3. Kaur A., Shah N., Logani A., Mishra N. Biotoxicity of commonly used root canal sealers: a metaanalysis. J Conserv Dent 2015;18:83-8.

4. Markowitz K, Moynihan M, Liu M, Kim S. Biologic properties of eugenol and zinc oxide-eugenol. A clinically oriented review. Oral Surg Oral Med Oral Path 1992;73:729-37.

5. Ashraf $H$, Najafi $F$, Heidari $S$, Mohammadian $M$, Zadsirjan $S$ physical properties and chemical characterization of two experimental epoxy resin root canalsealers. Iran Endod J. 2017;12:149-56

6. Jafari F, Aghazadeh M, Jafari S, Khaki F, Kabiri F In vitro Cytotoxicity Comparison of MTA Fillapex, $\mathrm{AH}$ 26 and Apatite Root Canal Sealer at Different Setting Times.Iran Endod J 2017;12:162-7.

7. Desai S., Chandler N. Calcium hydroxide-based root canal sealers: a review. J Endod 2009;35:475-80.

8. Kim Y K, Grandini S, Ames J. M, et al. Critical review on methacrylate resin-based root canal sealers. J Endod 2010;36:383-99.

9. Johnson WT, Gutmann JL. Obturation of the cleaned and shaped root canal system. In: Pathways of the pulp. "9nd Ed." Cohen S, Hargreaves K M. St. Louis: Mosby, 2006: p.368369.

10. Willershausen I, Callaway A, Briseno B, Willershausen $B$. In vitro analysis of the cytotocity and the antimicrobial effect of four endodontic sealers. Head Face Med 2011;15:1-9.

11. Vouzara T, Dimosiari G, Koulaouzidou EA, Economides N. Cytotoxicity of a new calcium silicate endodontic sealer. J Endod 2018;44:84952.

12. Baraba A, Pezelj-Ribaric S, Roguljic $M$, et al. Cytotoxicity of two bioactive root canal sealers. Acta Stomatol Croat 2016;50:8-13.

13. Mosmann T. Rapid colorimetric assay for cellular growth and survival: application to proliferation and cytotoxicity assays. J Immunol Methods 1983;65:55-63.

14. Economides N, Vassilie PKK, Poulupoulos A, Kolokuris I, Rozos G, Shore R. Experimental study of the biocompatibility of four root canal sealers and their influence on the zinc and calcium content of several tissues. J Endod 1995;21:1225. 
15. Schwarze T, Fiedler I, Leyhausen G, Geurtsen W. The cellular compatibility of five endodontic sealers during the setting period. J Endod 2002;28:784-6.

16. Lin PC, Chen WMW, Tai TF, Lee MY, Lin BR, Jeng $\mathrm{JH}$. Effects of root-end filling materials and eugenol on mitokondrial dehydrogenase activity and cytotoxicity to human periodontal ligament fibroblasts. Biomed Mater Res Part B: Apply Biometer 2004;71:429-40.

17. Rappaport, HM, Lilliy GE, Kapsimalis P. Toxicity of endodontic filling materials. Oral Surg Oral Med Oral Pathol 1964;18:785-02.

18. Cartwright, T., Shah, P. (1998). Culture media In: Basic cell culture: Ed. Davis JM, New York: Oxford Univercity Press, Pp.57-91.

19. Hensten-Pettersen A, Helgeland K. Evaluation of biologic effects of dental materials using different cell culture technique. Scand J Dent Res 1977;85:291-6.

20. Arun S, Sampath V, Mahalaxmi S, Rajkumar K. A comparative evaluation of the effect of the addition of pachymic acid on the cytotoxicity of 4 different root canal sealers-an in vitro study. J Endod 2017;43:96-9.

21. Javidi M, Zarei M, Omidi S, Ghorbani A, Gharechahi $M$, Shayani Rad $M^{4}$. Cytotoxicity of a New Nano Zinc-Oxide Eugenol Sealer on Murine Fibroblasts. Iran Endod J 2015;10:231-5.

22. Silva EJ, Neves AA, De Deus G, Accorsi-Mendonça T, Moraes AP, Valentim RM, Moreira EJ. Cytotoxicity and gelatinolytic activity of a new silicon-based endodontic sealer. J Appl Biomater Funct Mater 2015;13:376-80.

23. Eldeniz AU, Shehata M, Högg C, Reichl FX. DNA double-strand breaks caused by new and contemporary endodontic sealers. Int Endod J 2016;49:1141-51.

24. Poggio C, Riva P, Chiesa M, Colombo M, Pietrocola $G$ Comparative cytotoxicity evaluation of eight root canal sealers. J Clin Exp Dent. 2017;9:574-8.

25. Taira M, Nakao H, Matsumoto T, Takahashi J. Cytotoxic effect of methyl methacrylate on 4 cultured fibroblasts. Int J Prosthodont 2000;13:311-5.

26. Azar NG, Heidari M, Bahrami ZS, et al. In vitro cytotoxicity of a new epoxy resin root canal sealer. J Endod 2000;26:462-5.
27. Al-Hiyasat AS, Tayyar M, Darmani H. Cytotoxicity evaluation of various resin based root canal sealers. Int Endod J 2010;43:148-53.

28. Prüllage RK, Urban K, Sch€afer $E$, et al. Material properties of a tricalcium silicate- containing, a mineral trioxide aggregate-containing and an epoxy resin-based root canal sealer. J Endod 2016;42:1784-8.

29. Brackette MG, Lewis JB, Kious AR, Messer RLW, Lockwood PE, Brackette WW, Wataha JC. Cytotoxicity of endodontic sealers after one year of aging in vitro. J Biomed Mater Res B Appl Biomater 2012;100:1729-35

30. Karapinar-Kazandag M, Bayrak OF, Yalvac ME, Ersev H, Tanalp J, Sahin F, Bayirli G. Cytotoxicity of 5 endodontic sealers on $L 929$ cell line and human dental pulp cells. Int Endod J 2011;44:62634.

31. Leyhausen G, Heil J, Reifferscheid G, Waldmann P, Geursen W. Genotoxicity and cytotoxicity of the epoxy resin-based root canal sealer $\mathrm{AH}$ Plus. J Endod 1999;25:109-13.

32. Eldeniz, A.U., Mustafa, K., Qrstavik, D., Dahl, J.E. Cytotoxicity of new resin-calcium hydroxide, and silicone-based root canal sealers on fibroblasts derived from human gingiva and L929 cell lines. Int Endod J 2007;40:329-37.

33. Keleş A, Köseoğlu M, Çolak Topçu M, Bayrak ÖF. Farklı içerikli kök kanal patlarının sitotoksisitelerinin in vitro olarak incelenmesi . Atatürk Üniv Diş Hek Fak Derg 2009;19:90-7.

Scelza MZ, Linhares AB, Silva LE, Granjeiro JM, Alves GG. A multiparametric assay to compare the cytotoxicity of endodontic sealers with primary human osteoblasts. Int Endod J 2012;45:12-8

\author{
Yazışma Adresi \\ Dr. Dt. Funda Yılmaz \\ Ankara Üniversitesi \\ Diş Hekimliği Fakültesi, \\ Endodonti AD, Ankara, TÜRKİYE \\ Tel: 05055930693 \\ Email: dt.fndylmz@gmail.com
}

